\title{
EGYETEMISTÁK ÉS FŐISKOLÁSOK SZÍVBETEGSÉGGEL KAPCSOLATOS EGÉSZSÉGMAGATARTÁSA, RIZIKÓTUDATA ÉS HIEDELMEI
}

\author{
BARANYAI RÉKA ${ }^{1 *}$ - BAKOS GELLÉRT² - ANDREW STEPTOE ${ }^{3}$ \\ - JANE WARDLE ${ }^{4}-$ KOPP MÁRIA $^{1}$ \\ ${ }^{1}$ Semmelweis Egyetem, Magatartástudományi Intézet, Budapest \\ ${ }^{2}$ Städtisches Klinikum St. Georg, Leipzig \\ ${ }^{3}$ Psychobiology Group, Department of Epidemiology and Public Health, University \\ College London, UK \\ ${ }^{4}$ Department of Epidemiology and Public Health, University College London, UK
}

(Beérkezett: 2006. április 17.; elfogadva: 2006. április 26.)

\begin{abstract}
A kardiovaszkuláris kórképek okozta halálozás a fejlett társadalmakban vezetó helyen áll. Vizsgálatunkban felmértük, hogy a rizikótényezôk ismerete és az egészséges életmód különböző aspektusaihoz való hozzáállás milyen összefüggést mutat a kockázati és az egészségmagatartással. Módszerek: Az International Health and Behaviour Survey nemzetközi kutatás keretében országos reprezentatív keresztmetszeti vizsgálatot végeztünk egyetemisták és fóiskolások között. Önkitöltős kérdőívet alkalmazva a kardiovaszkuláris rizikófaktorok közül az egészségtelen életmódra (dohányzás, kevés mozgás, túlsúly, egészségtelen étrend) kérdeztünk rá, és vizsgáltuk a rizikótényezók ismeretét, illetve az egészséges életmóddal kapcsolatos attitüdöket is. A felmérésben 590 hallgató vett részt: 237 férfi (40,2\%) és 353 nó (59,8\%). A hallgatók életkora 18 és 28 év között volt, átlagéletkoruk 21,8 év $( \pm 1,8)$. Többváltozós logisztikus regressziós modelleket alkalmaztunk, eredményeinket nemre és korra kontrolláltuk. Eredmények: Magatartás: A diákok 19,4 \%-a dohányzott és 9,5\%-a túlsúlyosnak bizonyult. A hallgatók 84\%-a legalább egyszer sportolt két hét alatt. Az egészséges étrend prevalenciája alacsonyabb a fentebb említett tényezókéhez képest: napi egyszeri gyümölcsfogyasztásról a diákok 35,7\%-a számolt be, 30,7\% igyekezett csökkenteni a koleszterin- és zsírbevitelt, illetve 23,9\% fogyasztott tudatosan rosttartalmú ételeket. Ismeretek: Míg a túlsúlyt és a fokozott koleszterin- és zsírbevitelt a diákok több mint háromnegyede említette, addig a dohányzás és a kevés testmozgás szerepét a hallgatók mintegy fele ismerte (55,3\% és 42,8\%). A rostfogyasztásról csak 18,4\% tett említést. Attitüdök: A legtöbben a rendszeres testmozgást tartották fontosnak (93,1\%), ezt követte a gyümölcsfogyasztás $(90,8 \%)$, a normális testsúly megtartása $(87,8 \%)$ és a dohányzás mellózése $(86,4 \%)$. Ezzel szemben a rostfogyasztás és a kevés állati zsír fogyasztása a hallgatók csak kevesebb mint kétharmada számára volt fontos (61,2\% és 59,3\%). A szívbetegség rizikófakto-
\end{abstract}

\footnotetext{
* Levelezô szerző: Dr. Baranyai Réka, Semmelweis Egyetem, Magatartástudományi Intézet. 1089 Budapest, Nagyvárad tér 4. E-mail: rekabaranyai@hotmail.com
} 
rainak ismerete igen kevés kapcsolatot mutatott a magatartással (a dohányzásnál találtunk pozitív összefüggést). Az attitüdök - a rizikótudattal ellentétben - igen jelentôs szerepet játszottak, szinte minden magatartásforma esetében. Következtetések: A diákok között továbbra is igen magas a kardiovaszkuláris rizikómagatartás prevalenciája. A rizikófaktorok ismerete önmagában nem járult hozzá ahhoz, hogy a diákok egészségesebben éljenek. Ha az egészséges életmód fontos értéket képviselt számukra, akkor gyakrabban sikerült az egészséges magatartásformát megvalósítaniuk.

Kulcsszavak: hallgatók, egészségmagatartás, koronáriás szívbetegség, rizikófaktorok ismerete, attitúdök, hiedelmek

A kardiovaszkuláris kórképek okozta halálozás a fejlett társadalmakban vezetô helyen áll. Az Egészségügyi Világszervezet jelentése szerint 2002ben 16,7 millióan haltak meg kardiovaszkuláris betegség következtében. Az iszkémiás szívbetegség - mint a leggyakoribb kardiovaszkuláris kórkép - a teljes halálozás 13\%-áért tehetó felelőssé. Nem elhanyagolható az a tény sem, hogy évente legalább 20 millió beteg túléli az infarktust, ellátásuk pedig az egészségügy jelentôs forrásait veszi igénybe. Az infarktus a középkorúakat érinti a leginkább, és mivel a betegek jelentős része nem tér vissza munkahelyére, anyagi és a pszichoszociális jóllétük nagymértékben romolhat. A betegség nemcsak az egyén életét befolyásolja, hanem a családokat, a munkahelyeket és az egészségügyi ellátást is megterheli (WHO 2003).

Bár az elmúlt évtizedekben a szívinfarktus elófordulása a fejlett országokban csökkent, és a prognózis is jelentôsen javult, a közép-kelet-európai régióban ezzel szemben az incidencia emelkedett (Fox és mtsai 2004; Yusuf és mtsai 2001). A WHO elörejelzése szerint a halálozás világszerte még tovább emelkedik a következó évtizedekben, és 2020-ra a koronáriás szívbetegség lesz felelős a halálozás 30\%-áért (WHO 2003).

Az elmúlt évek során számos tanulmány hívta fel a figyelmet arra, hogy az egészségtelen életmód (dohányzás, kevés mozgás, túlsúly, egészségtelen étrend) a szívbetegség kialakulásában kulcsfontosságú szerepet tölt be (Yusuf és mtsai 2004). Mivel ezek a tényezók módosíthatók, számos prevenciós program túzte ki célul e káros magatartásformák megváltoztatását. Ezen programok sikere elengedhetetlen annak érdekében, hogy az infarktus előfordulását csökkenteni tudjuk. Ezért nagyon fontos kérdés az, milyen tényezók befolyásolhatják az egészséges életmód kialakulását.

Kutatásunkban a fentiek tükrében azt vizsgáltuk, hogy a rizikótényezốk ismerete és az egészséges életmód különbözó aspektusaihoz való hozzáállás milyen összefüggést mutat a magatartással. Mivel a prevenciós programok hatékonysága várhatóan az iskolázottabb rétegben a legnagyobb, egyetemistákat és fóiskolásokat kérdeztünk meg. 
Vizsgálatunkban egyrészt felmértük az egészség- és a kockázati magatartás prevalenciáját, a szívbetegség rizikófaktorainak ismeretét, valamint azt, hogy a diákok hány százaléka tartja fontosnak az egészséges életmódra jellemzó egyes magatartásmintákat. Másrészt többváltozós regressziós modellekkel arra a kérdésre kerestük a választ, hogy az ismeretek vagy az attitúdök befolyásolják-e jobban a magatartást.

\section{MÓDSZEREK}

Magyarországi vizsgálatunk a University College London kutatói, Andrew Steptoe és Jane Wardle professzorok vezetésével zajló International Health and Behaviour Study nemzetközi kutatás része. Az azonos metodika miatt eredményeink a nemzetközi adatokkal is összehasonlíthatóak. Mivel az egészséges életmóddal kapcsolatos információk, hiedelmek és attitúdök hatását elemeztük, olyan diákokat vontunk be a kutatásba, akik nem szakmai tudásról számolhattak be, azaz nem egészségügyi felsőoktatási intézményekben tanultak. Országos keresztmetszeti vizsgálatot terveztünk: a Központi Statisztikai Hivatal adatai alapján választottuk ki a tanulmányi ágakat, valamint régiónként (Kelet-, Nyugat-Magyarország, illetve Budapest/Pest megye) az egyetemeket/fóiskolákat. Az adatgyújtést önkitöltéses kérdôíves módszerrel végeztük. A diákok önkéntes alapon vehettek részt a kutatásban. A végsó minta eltérése a KSH adataihoz képest a megengedhetô statisztikai túréshatárok között mozgott, ezért a felmérés országosan reprezentatívnak tekinthetó.

590 diáktól kaptunk vissza értékelhető kérdőívet, a visszautasítás aránya 10\% alatt volt. Mintánkban 237 (40,2\%) férfi és 353 nó $(59,8 \%)$ szerepelt. A hallgatók életkora 18 és 28 év között volt, átlagéletkoruk 21,8 év $( \pm 1,8)$.

\section{Vizsgált változók}

Vizsgálatunkhoz a nemzetközi felméréshez összeállított eredeti angol kérdôívet fordítottuk le magyar nyelvre. A kérdóív rövid és hosszú távú reliabilitása megfelelónek bizonyult (Steptoe és mtsai 1995; Wardle és Steptoe 1991). Három, egymástól független oda-vissza fordítás alapján állítottuk össze a végleges változatot, mely a következő elemekból állt:

Egészség- és kockázati magatartás. Két rizikómagatartási mintára (dohányzás, túlsúly) valamint két egészségmagatartásra (sportolás, egészséges étrend) kérdeztünk rá. A dohányzással kapcsolatban hét választási lehetôség volt: „nem cigarettázom, még egy slukkot sem szívtam”, 
„valamikor régen egy vagy két cigarettát elszívtam”, „régen dohányoztam, de leszoktam róla”, "nem cigarettázom, viszont szivarozom vagy pipázom”, ,naponta általában 1-10 szál cigarettát szívok”, ,"naponta általában 10-20 szál cigarettát szívok”, „naponta általában több mint 20 szál cigarettát szívok". Dohányosnak tekintettük azokat a diákokat, akik jelenleg legalább napi 1-10 szál cigarettát szívtak el, szivaroztak vagy pipáztak.

A túlsúlyt a magasságból és a testsúlyból számított testtömeg-index (BMI) révén határoztuk meg: $25 \mathrm{~kg} / \mathrm{m}^{2}$ és afeletti értéket túlsúlyként értékeltünk.

A sportolást a következó kérdésekkel mértük fel: „Az elmúlt 2 hétben (14 nap) végzett-e valamilyen testmozgást?” és „Ha igen, hány alkalommal végzett testmozgást az elmúlt 2 hétben?". Az Egészségügyi Világszervezet ajánlását figyelembe véve a válaszok alapján három csoportra osztottuk a diákokat: inaktív (egyáltalán nem sportol), valamennyit (maximum 3 alkalommal), ajánlott szinten (legalább 4 alkalommal). Elemzéseink során megvizsgáltuk az egyáltalán nem sportolók (inaktívak) és a két hét alatt legalább egyszer sportolók (aktívak), illetve az ajánlott szinten és a kevesebbet mozgó diákok jellemzóit.

Az egészséges étrendet az alábbi kérdésekkel vizsgáltuk: „Tudatosan törekszik-e arra, hogy elkerülje a zsír- és koleszterintartalmú ételeket?", "Tudatosan törekszik-e arra, hogy rostban gazdag ételeket fogyasszon?"; „Hányszor eszik gyümölcsöt?”. A zsír- és koleszterinbevitel korlátozásánál és a rostfogyasztásnál igennel, illetve nemmel lehetett válaszolni, a gyümölcsfogyasztásnál pedig a következố válaszok álltak rendelkezésre: "legalább egyszer naponta”, „2-3 naponta”, ,kb. hetente egyszer”, "kevesebbszer, mint hetente egyszer", „soha”. Gyümölcsfogyasztónak tekintettük azokat a diákokat, akik legalább napi rendszerességgel fogyasztottak gyümölcsöt.

Vizsgáltuk az egészséges életmód fontosságát, azaz az egészséges életmóddal kapcsolatos hiedelmeket, valamint a szívbetegséggel kapcsolatos rizikófaktorok ismeretét is.

Az egészséges életmód fontossága: A diákok egy 1-tól 10-ig terjedó skálán jelölhették be, hogy mennyire tartják fontosnak az egyes magatartásformákat, ahol az 1-es érték „egyáltalán nem fontos”, míg a 10-es érték „nagyon fontos" volt. Az alábbi állítások értékelésére kértük az egyetemistákat és fóiskolásokat: fontos-e: „nem dohányozni”, "a rendszeres testedzés", „, a normális testsúlyt megtartani”, „nem túl sok állati zsiradékot fogyasztani”, , elég rostos ételt fogyasztani”, , elég gyümölcsöt fogyasztani". A logisztikus regressziós modellhez a változót a következóképpen dichotomizáltuk: 1-5 = kissé fontos, $6-10=$ fontos. 
Szívbetegséggel kapcsolatos kockázati tényezók ismerete: A diákok egy felsorolásból választhatták ki, hogy véleményük szerint mely tényezố befolyásolhatja akár pozitívan, akár negatívan a szívbetegség kialakulását. A rendelkezésre álló tényezók az alábbiak voltak: dohányzás, testmozgás, túlsúly, öröklődés, állati zsiradék fogyasztása, rostfogyasztás, stressz.

\section{Statisztikai elemzés}

Az adatfeldolgozást az SPSS 9.0 for Windows programcsomag segítségével végeztük. Szignifikánsnak a p<0,05 értékeket tekintettük. Az elemzések során leíró statisztikákat (átlag, szórás, gyakorisági megoszlás), összehasonlító statisztikákat ( $\chi^{2}$-próbát) alkalmaztunk az egészséges magatartásnak, a rizikófaktorok ismeretének, illetve az attitúdöknek a vizsgálatára. Többváltozós bináris logisztikus regresszióanalízist végeztünk azzal a céllal, hogy felderítsük, az ismeretek vagy az egészségmagatartás fontossága határozza-e meg jobban a magatartást, ha a kor és a nem szerinti különbségeket figyelembe vesszük.

\section{EREDMÉNYEK}

Az 1. táblázat az egészséges és a káros magatartás elófordulását mutatja be, nemek szerinti bontásban is. A diákok 19,4\%-a dohányzik és 9,5\%-a túlsúlyos. A hallgatók $84 \%$-a legalább egyszer sportolt két hét alatt, azonban legalább négyszer, azaz a kardiovaszkuláris protektív hatás eléréséhez szükséges mértékben már csak 54,7\%. Az egészséges étrend prevalenciája alacsonyabb a fentebb említett tényezókéhez képest: napi egyszeri gyümölcsfogyasztásról a diákok 35,7\%-a számolt be, 23,9\% fogyasztott tudatosan rosttartalmú ételeket, 30,7\% igyekezett csökkenteni a koleszterin- és zsírbevitelt.

A nemek szerinti különbséget $\chi^{2}$ próbával szignifikánsnak találtuk. A nók sokkal jobban odafigyeltek az étrendjükre: több gyümölcsöt és rosttartalmú ételt ettek, és odafigyeltek arra is, hogy alacsony koleszterintartalmú ételeket fogyasszanak.

A 2. táblázatból kitúnik, hogy a diákok hány százaléka ismerte a szívbetegség kockázati tényezóit. Érdekes, hogy míg a túlsúlyt, illetve a fokozott koleszterin- és zsírbevitelt a diákok több mint háromnegyede említette, addig a dohányzás és a kevés testmozgás szerepét a hallgatók mintegy fele ismerte (55,3\% és 42,8\%). A rostfogyasztásról még kevesebben, csak 18,4\%-ban tettek említést. A stresszt és a megfelelő stresszkezelés 
1. táblázat. Az egészséges és káros magatartásformák prevalenciája egyetemi és fóiskolai hallgatóknál ( $n=590)$

\begin{tabular}{|l|c|c|c|c|}
\hline & Férfiak & Nők & $\begin{array}{c}\text { Teljes } \\
\text { minta }\end{array}$ & P \\
\hline Dohányzás & $19,5 \%$ & $19,3 \%$ & $19,4 \%$ & $\mathrm{n} . \mathrm{s}$ \\
\hline Testmozgás & & & & \\
\hline $\begin{array}{l}\text { Ajánlott szint } \\
\text { (legalább 4-szer sportolt az elmúlt 2 hétben) }\end{array}$ & $59,3 \%$ & $51,6 \%$ & $54,7 \%$ & 0,064 \\
\hline Aktív (legalább 1-szer sportolt az elmúlt 2 hétben) & $85,2 \%$ & $83,2 \%$ & $84,0 \%$ & n.s. \\
\hline Túlsúly BMI =25 & $15,7 \%$ & $5,4 \%$ & $9,5 \%$ & $<0,001$ \\
\hline Elhízás BMI = 30 & $1,3 \%$ & $1,7 \%$ & $1,5 \%$ & n.s. \\
\hline Étrend & & & & \\
\hline Gyümölcsfogyasztás legalább 1-szer naponta & $29,7 \%$ & $39,8 \%$ & $35,7 \%$ & 0,012 \\
\hline Rosttartalmú ételek fogyasztása & $12,8 \%$ & $31,4 \%$ & $23,9 \%$ & $<0,001$ \\
\hline $\begin{array}{l}\text { Alacsony koleszterin- és zsírtartalmú ételek } \\
\text { fogyasztása }\end{array}$ & $21,7 \%$ & $36,6 \%$ & $30,7 \%$ & $<0,001$ \\
\hline
\end{tabular}

hiányát $71 \%$ jelölte meg. Az örökletes tényezókre majdnem $70 \%$ hivatkozott.

Több férfi ismerte a dohányzás káros hatását, míg több nó a rostszegény étrend szerepét. Más kockázati tényezóknél nem találtunk a nemek között eltéréseket.

A 3. táblázat mutatja be a diákok egészséges életmóddal kapcsolatos attitúdjeit. Legtöbben a rendszeres testmozgást tartották fontosnak (93,1\%), ezt követte a gyümölcsfogyasztás $(90,8 \%)$, és hasonló százalékokat találtunk a dohányzás mellózése $(86,4 \%)$, illetve a normális testsúly megtartása $(87,8 \%)$ kapcsán. Ezzel szemben a rost- és kevés állatizsír-fogyasztás a hallgatók csak kevesebb mint kétharmada számára volt fontos (61,2\% és 59,3\%). A nók gyakrabban számoltak be arról, hogy fontos számukra

2. táblázat. A szívbetegség kialakulását befolyásoló tényezók ismerete ( $\mathrm{n}=586)$

\begin{tabular}{|l|c|c|c|c|}
\hline & Férfiak & Nôk & $\begin{array}{c}\text { Teljes } \\
\text { minta }\end{array}$ & P \\
\hline Dohányzás & $63,4 \%$ & $49,9 \%$ & $55,3 \%$ & 0,001 \\
\hline Kevés testmozgás & $39,6 \%$ & $45,0 \%$ & $42,8 \%$ & n.s. \\
\hline Túlsúly & $92,3 \%$ & $93,7 \%$ & $93,2 \%$ & n.s. \\
\hline Étrend & & & & \\
\hline Túlzott koleszterin- és zsírbevitel & $73,6 \%$ & $76,6 \%$ & $75,4 \%$ & n.s. \\
\hline Rostszegény étrend & $14,5 \%$ & $21,1 \%$ & $18,4 \%$ & 0,043 \\
\hline Stressz & $69,4 \%$ & $72,1 \%$ & $71,0 \%$ & ns \\
\hline Örökletes genetikai tényezók & $66,8 \%$ & $71,8 \%$ & $69,9 \%$ & ns \\
\hline
\end{tabular}


3. táblázat. Az egészséges életmóddal kapcsolatos attitúdök $(\mathrm{n}=590)$

\begin{tabular}{|l|c|c|c|c|}
\hline & Férfiak & Nók & $\begin{array}{c}\text { Teljes } \\
\text { minta }\end{array}$ & $\mathrm{P}$ \\
\hline Dohányzás mellózése & $83,1 \%$ & $88,7 \%$ & $86,4 \%$ & 0,054 \\
\hline Rendszeres testmozgás & $89,5 \%$ & $95,5 \%$ & $93,1 \%$ & 0,005 \\
\hline $\begin{array}{l}\text { Testsúlyt a megfeleló tartományban } \\
\text { tartani }\end{array}$ & $80,6 \%$ & $92,6 \%$ & $87,8 \%$ & $<0,001$ \\
\hline Étrend & & & \\
\hline $\begin{array}{l}\text { Gyümölcsfogyasztás } \\
\text { Rostfogyasztás }\end{array}$ & $83,5 \%$ & $95,8 \%$ & $90,8 \%$ & $<0,001$ \\
\hline Állatizsiradék fogyasztásának korlátozása & $41,8 \%$ & $71,4 \%$ & $61,2 \%$ & $<0,001$ \\
\hline
\end{tabular}

az egészséges életmód (a dohányzásnál csak trendet találtunk). Különösen az étrend kapcsán tapasztaltunk jelentôs különbségeket.

Többváltozós logisztikus regressziós modellel határoztuk meg, hogy nemre és korra történó kontrollálás után a kockázati tényezók ismerete, valamint az attitúdök összefüggést mutattak-e a magatartással. Függó változóként alkalmaztuk az egyes magatartásformákat. A 4. táblázatban tüntettük fel a bináris logisztikus regresszió során kapott esélyhányadosok értékeit az egyes magatartásformák esetén. Megadtuk a 95\%-os konfidencia intervallumokat is.

A szívbetegség rizikófaktorainak ismerete igen kevés kapcsolatot mutatott a magatartással: csupán egy összefüggést találtunk. Azonban ez az összefüggés a várthoz képest ellenkezó irányt mutatott: nagyobb eséllyel dohányoztak azok, akik tudták, hogy a dohányzás a szívbetegség rizikó-

4. táblázat. A hiedelmek és a rizikófaktorok ismeretének összefüggése a magatartással, korra és nemre történő kontrollálás után $(\mathrm{n}=590)$

\begin{tabular}{|l|c|c|}
\hline Független változó & $\begin{array}{c}\text { A szívbetegség } \\
\text { rizikófaktorának } \\
\text { ismerete } \\
\text { OR }(95 \% \mathrm{KI})\end{array}$ & $\begin{array}{c}\text { Fontosnak tartja } \\
\text { az egészséges } \\
\text { magatartást } \\
\text { OR }(95 \% \mathrm{KI})\end{array}$ \\
\hline Dohgón változó & $\begin{array}{c}1,69(1,10-2,61)^{*} \\
0,10(0,06-0,18)^{* * *}\end{array}$ \\
\hline Testmozás (dohányzik (ajánlott vs. kevesebb) & $0,84(0,60-1,17)$ & $1,90(0,99-3,65)^{\circ}$ \\
\hline Testmozgás (inaktív vs. aktív) & $0,94(0,65-1,36)$ & $1,46(1,31-1,66)^{* * *}$ \\
\hline Túlsúly (BMI = 25 vs. BMI < 25) & $0,58(0,23-1,49)$ & $1,05(0,47-2,40)$ \\
\hline Étrend & & \\
\hline Állatizsír-bevitel korlátozása (igen - nem) & $1,18(0,77-1,79)$ & $8,67(5,14-14,54)^{* * *}$ \\
\hline Rostfogyasztás (igen - nem) & $1,09(0,67-1,78)$ & $4,07(2,45-6,79)^{* * *}$ \\
\hline Gyümölcsfogyasztás (igen - nem) & & $2,27(1,10-4,67)^{*}$ \\
\hline
\end{tabular}

${ }^{\circ} p=0,052 .{ }^{*} p<0,05 .{ }^{* * *} p<0, .001$. 
faktora, mint azok, akik nem tudtak erról - tehát a dohányzók között többen hallottak arról, hogy magatartásuknak milyen káros következményei lehetnek.

Az attitüdök - a rizikótudattal ellentétben - igen jelentôs szerepet játszottak szinte minden magatartásforma esetében, akkor is, ha figyelembe vettük a kor és a nem hatását. Azok, akik fontosnak tartották az egészséges életmódot, kevésbé dohányoztak, és sokkal inkább odafigyeltek az étrendjükre. A sportolás szempontjából: azon diákok között, akiknek az a véleménye, hogy a testmozgás fontos az egészség megórzése céljából, többen sportoltak. Tehát az attitúdnek szignifikáns hatása volt abban, hogy a diákok végeztek-e egyáltalán testmozgást. Ezzel szemben, amikor megvizsgáltuk, van-e valamilyen szerepe a hozzáállásnak abban, hogy a sportolás frekvenciája emelkedjék, azaz a diákok két hét alatt legalább négyszer sportoljanak, csak tendenciát tapasztaltunk. A túlsúllyal kapcsolatban nem találtunk összefüggést.

A nókre egészségesebb magatartás volt jellemzó a férfiakhoz képest, ha ugyanolyan mértékben ismerték a dohányzás, a túlsúly, a rostszegény táplálkozás, illetve a túlzott zsírbevitel káros hatásait. A nók egészségesebben éltek a férfiaknál akkor is, ha ugyanolyan fontosnak tartották az egészséges magatartást, mint a férfiak (a rost- és gyümölcsfogyasztás, valamint a normális testsúly megtartása esetében).

\section{MEGBESZÉLÉS}

Vizsgálatunk az első olyan, országos reprezentatívnak tekinthetô kutatás Magyarországon, amely a kardiovaszkuláris rizikófaktorok ismeretének, illetve az egészséges életmóddal kapcsolatos attitúdöknek a kapcsolatát elemzi az egészségkárosító és az egészségmegőrző magatartással. Mivel a nemzetközi felmérés módszertana azonos volt, kutatásunk lehetôséget teremt más európai országok adataival történó összehasonlításokra.

Az egyetemisták és fóiskolások képezik a társadalomnak azt a rétegét, amely az elkövetkezó években a gazdasági, politikai és tudományos életben meghatározó szerepet játszik majd, hiszen nagy eséllyel közülük kerülnek ki a közép- és felsóvezetók, az oktatók, a törvényalkotók, akik mind helyi, mind országos szinten jelentős befolyást gyakorolhatnak a társadalomra. Ezért ennek a rétegnek az egészségmagatartását, az egészséges életmóddal kapcsolatos attitúdjeit és a különböző betegségek rizikófaktorainak ismeretét igen fontos megvizsgálnunk, illetve jó irányban alakítanunk. Kutatásunkat ezért felsôoktatási intézményben tanuló diá- 
kok körében végeztük az egyik népbetegség, a koronáriás szívbetegség szempontjából fontos kockázati és egészségmagatartásra, ismeretekre és hozzáállásra koncentrálva.

Általánosságban elmondhatjuk, hogy az egyetemisták és főiskolások ismeretei a szívbetegség kockázati tényezóivel kapcsolatban igen hiányosak. Feltétlenül kiemelendô, hogy még ennél a népegészségügyi szempontból korántsem elhanyagolható betegségnél is a diákok mintegy fele nem tudja, hogy a dohányzás és a testmozgás hiánya rizikófaktor, és kevesebb mint egyötödük hallott arról, hogy a rostszegény étrendnek is káros hatása lehet.

Ezek az adatok még jelentősebbek annak tükrében, hogy ezek a diákok alkotják korosztályuk legképzettebb rétegét, akiknél a legvalószínúbb, hogy megfeleló információkkal rendelkeznek. Összehasonlítva a nemzetközi adatokkal a magyar diákok ismeretei az európai átlag alatt találhatóak (bár az európai adatok sem magasak: a diákok mintegy kétharmada jelölte meg a dohányzást, és csupán mintegy fele a testmozgás hiányát) (Steptoe és mtsai 2002a). A legismertebb a túlsúly, valamint a koleszterinés zsírbevitel szerepe, mely feltételezésünk szerint részben a különbözó médiák által sugallt „karcsúságideál” következménye is lehet.

A prevenciós programok alappillére az információközlés, a tájékoztatás. Ezért kíváncsiak voltunk arra is, hogy milyen mértékben befolyásolja a viselkedést az információk ismerete. Vizsgálatunkban a rizikófaktorok ismerete önmagában nem járult hozzá ahhoz, hogy a diákok egészségesebben éljenek. Sót, a dohányzók között többen tudták, hogy magatartásuknak milyen káros következményei lehetnek, megerósítve más kutatások megfigyeléseit (Stachenko és mtsai 1992; Steptoe és mtsai 2002b). Több hipotézis született e meglepó összefüggés magyarázatára: a rizikótudatot más kognitív tényezók enyhíthetik, mint például az, hogy bármikor abbahagyhatják, elfogultak lehetnek saját vulnerabilitásukkal kapcsolatban, kevésbé jővőorientáltak, és kevésbé foglalkoznak a távoli jővóben várható szövődményekkel (Keough és mtsai 1999).

Az egészséges életmóddal kapcsolatos attitûdök, hiedelmek és az egészséges magatartás között azonban robusztus összefüggést tapasztaltunk a dohányzás, az étkezési szokások, és kisebb mértékben a sportolás esetében is, más európai országokhoz hasonlóan (Steptoe és mtsai 2002a). Ez az eredmény arra hívja fel a figyelmet, hogy a primer prevenció során a felvilágosító programok alkalmazása mellett más stratégiákra is szükség van.

Azért is fontos elgondolkodni azon, hogyan lehetne az egészségmagatartást fejleszteni, mert kutatásunk rávilágít arra, hogy az eddigi prevenciós erófeszítések ellenére a kardiovaszkuláris rizikómagatartás preva- 
lenciája továbbra is magas. Az egyetemisták és fôiskolások egészségmagatartása több kívánnivalót is hagy maga után.

A hallgatók mintegy fele sportol a kardiovaszkuláris védó hatáshoz elegendó mértékben, és minden ötödik diák dohányzik. Egészségügyi felsóoktatási intézményben tanuló diákoknál is hasonló mértékú dohányzást írtak le egy 2000-ben készült vizsgálatban, mely egy idóben zajlott a mi kutatásunkkal (Sima és mtsai 2004), illetve 1995-ben orvostanhallgatóknál Szegeden (Pikó és mtsai 1996). Korábbi kutatások azt találták, hogy az egyetemisták egészségesebben élnek, mint más társadalmi rétegek (Patrick és mtsai 1992). A felsőfokú végzettséggel rendelkezók többet sportolnak (Martinez-Gonzalez és mtsai 2001), kevésbé dohányoznak, és hajlamosabbak abbahagyni a dohányzást (Jarvis és mtsai 1999), mint az alacsonyabb végzettségúek. Hazai vizsgálatok alapján is azt feltételezhetjük, hogy az egyetemi és fóiskolai hallgatók egészségesebben élnek, mint a korosztályuk: budapesti gimnazisták között a dohányzás prevalenciája 43,1\% volt, míg szakmunkástanulók és szakközépiskolások között 60,2\% (Easton és Kiss 2005); szegedi középiskolás fiúk 41,8\%-a, míg a lányok 38,8\%-a dohányzott (Pikó és Fitzpatrick 2004). Mintánkban nem találtunk nemi különbséget a dohányzás terén. Ugyanerre a megállapításra jutott az egészségügyi intézményben tanuló diákokat vizsgáló tanulmány (Sima és mtsai 2004), valamint Kopp és Skrabski 1990-ben végzett vizsgálata (Kopp és Skrabski 1995). Más országokban végzett felmérések azt mutatják, hogy nagy különbségek vannak abban, hogy a diákok hány százaléka dohányzik, illetve sportol. Európai adatokkal összehasonlítva azt látjuk, hogy a magyar diákok az európai átlaghoz képest kevésbé dohányoznak, és többet sportolnak (Steptoe és mtsai 2002a).

A túlsúllyal kapcsolatban fontos kiemelnünk, hogy már ebben a korosztályban is a férfiak 15,6\%-a és a nók 5,1\%-túlsúlyos. Korábbi kutatások rámutattak arra, hogy a vizsgálati személyek gyakran alábecsülik a valós testsúlyukat, különösen a nók hajlamosak erre (Brener és mtsai 2003). Ezért valószínúsíthetjük, hogy a túlsúly valódi prevalenciája ennél magasabb a diákok körében. Figyelembe véve azt, hogy a túlsúly a koronáriás szívbetegség egyik fó rizikófaktora, és serdülókori, fiatalkori túlsúly esetén a szívbetegséghez vezetô patofiziológiai folyamatok felgyorsulhatnak (Daniels 2006), a prevenciónak igen fontos szerepe lenne ennél a korosztálynál (és a fiatalabbaknál is).

Az étkezési szokások terén különösen szembetúnó, milyen kevesen étkeznek egészségesen: a diákok alig egyharmada. Ez az arány az európai átlaghoz képest is nagyon alacsonynak tekinthető, ugyanakkor más országokban is a helyes étkezési szokások prevalenciája volt a legalacsonyabb a vizsgált egészségmagatartások közül (Steptoe és mtsai 2002a). 
A nók várakozásunknak megfelelóen sokkal inkább odafigyelnek az étrendjükre, mint a férfiak. Ez összefügghet azzal, hogy a lányok gyerekkoruk óta arra szocializálódnak, hogy önmaguk és családjuk számára az ételeket kiválasszák és elókészítsék, és az így megszerzett készségeket alkalmazzák arra, hogy egészségesebb ételeket fogyasszanak (Rappoport és mtsai 1993). A férfiak hajlamosabbak a kényelmet és az ízlésüket elóbbre helyezni, mint azt, hogy egészséges-e egy étel (Fagerli és Wandel 1999; Wardle és Solomons 1994; Wardle és mtsai 2004). A nemi különbség hátterében állhat az is, hogy a nók jobban aggódnak a testsúlyuk miatt, és többet diétáznak (Bellisle és mtsai 1995; Serdula és mtsai 1993), a diéták pedig gyakran több gyümölcs és zöldség fogyasztását, illetve zsírszegény ételeket javasolnak.

A megfigyelt nemi különbségek kapcsán szeretnénk arra rámutatni, hogy az egyetemista és fóiskolás nók egészségesebben élnek, és az egészséges magatartásformákat is fontosabbnak tartják, mint a férfiak. Mivel a férfiak a kardiovaszkuláris rizikó szempontjából veszélyeztetettebbek, a prevenció során a férfiak elérésére, motiválására külön figyelmet kell fordítani. Ennek során célszerú figyelembe venni, hogy - úgy túnik - a férfiak hajlamosabbak a „lexikális tudást” az életvitelüktól függetlenül kezelni, arról leválasztani.

A fenti eredmények tükrében elmondhatjuk azt, hogy nem elég az egyes rizikótényezókról szóló információ átadása, hanem arra is szükség van, hogy a tudás internalizálódjék, meggyôzódéssé váljék. Ehhez nagyon fontos a példamutatás, illetve olyan lehetôségek teremtése, ahol az egészséges életmód gyakorolható, megtartható (pl. játszóterek, tornatermek, uszodák, otthoni és iskolai egészséges étkezés, füstmentes iskolák, középületek stb.). Kutatások is igazolták, hogy a lehetôségek megteremtése egészségesebb életmóddal jár együtt: a testmozgás idótartama és intenzitása korrelált azzal, milyen közel volt a diákokhoz a sportolás helyszíne (Reed és Philips 2005). Ugyanakkor elengedhetetlen az is, hogy ne csak általános ajánlásokat fogalmazzunk meg, hanem konkrét, aktív javaslatok is hangozzanak el a primer prevenciós programok során, hogyan élhetnek egészségesen (edzésprogram, diétás étrend szétosztása stb.), illetve olyan közösségi programokat szervezzünk, amelyeken a diákok együtt sajátíthatják el az egészséges életmód alappilléreit, mint pl. a rendszeres testmozgást, a megfeleló étrendet. Kutatások szerint a dohányzásról való leszokáshoz még inkább szükség van a pontos utasításokra arról, hol, mikor és hogyan lehet valamilyen lépést tenni a megelôzés érdekében (Leventhal 1970). A pontos információ mellett azonban a kockázat tudatosítását, azaz egy "egészséges félelem” kiváltását is fontosnak találták. 
Csak akkor érhetjük el, hogy a kardiovaszkuláris morbiditási és mortalitási adatok az elkövetkezó években csökkenjenek, ha egy széles körú összefogás valósul meg; ha az egyén, a családok, az oktatási intézmények, a munkahelyek, valamint a népegészségügyi szakemberek és a törvényalkotók is prioritásnak tekintik az egészséges életmód kialakítását, fennmaradását.

Összefoglalásként megállapíthatjuk, hogy az egyetemisták és fóiskolások egészségmagatartása kívánnivalókat hagy maga után. Kutatásunk felhívja a figyelmet arra, hogy a primer prevenció során a felvilágosító programok mellett az attitúdök kialakítására, módosítására is érdemes nagy hangsúlyt fektetni, lehetóségek és konkrét programok megteremtése által. Az egyén, a család, az iskolák, a munkahelyi vezetók, a média, a népegészségügyi szakemberek és a kormányzat összehangolt, egymást támogató tevékenysége által sikerülhet olyan feltételeket teremteni, amelyek lehetôvé teszik az egészséges életmód kialakulását és megtartását.

\section{Irodalom}

Bellisle, F., Monneuse, M. O., Steptoe, A., Wardle, J. (1995): Weight concerns and eating patterns: a survey of university students in Europe.International Journal of Obesity and Related Metabolic Disorders, 19 (10): 723-730.

Brener, N. D., Mcmanus, T., Galuska, D. A., Lowry, R., Wechsler, H. (2003): Reliability and validity of self-reported height and weight among high school students. Journal of Adolescent Health, 32 (4): 281-287.

Easton, A., Kiss, E. (2005): Covariates of current cigarette smoking among secondary school students in Budapest, Hungary, 1999. Health Education Research, 20 (1):92-100.

Daniels, S. R. (2006): The consequences of childhood overweight and obesity. The Future of children / Center for the Future of Children, the David and Lucile Packard Foundation. 16 (1): 47-67.

Fagerli, R. A., Wandel, M. (1999): Gender differences in opinions and practices with regard to a „Healthy Diet." Appetite, 32 (2): 171-190.

Fox, C. S., Evans, J. C., Larson, M. G., Kannel, W. B., Levy, D. (2004): Temporal trends in coronary heart disease mortality and sudden cardiac death from 1950 to 1999: the Framingham Heart Study. Circulation, 110 (5): 522-527.

Jarvis, M. J., Wardle, J. (1999): Social patterning of individual health behaviours: the case of cigarette smoking. In: Marmot, M. G., Wilkinson, R. G. (eds.): Social Determinants of Health. Oxford University Press, Oxford, 240-255.

Keough, K. A., Zimbardo, P. G., Boyd, J. N. (1999): Who's smoking, drinking, and using drugs? Time perspective as a predictor of substance use. Basic and Applied Social Psycho$\log y, 21:$ 149-164.

Kopp M., Skrabski Á. (1995): Magyar lelkiállapot. Végeken Alapítvány, Budapest.

Leventhal, H. (1970): Findings and theory in the study of fear communications. In Berkowitz, L. (ed.): Advances in Experimental Social Psychology. Vol. 5. Academic Press, New York, 119-186.

Martinez-Gonzalez, M. A., Varo, J. J., Santos, J. L., De Irala, J., Gibney, M., Kearney, J., 
Martinez J. A. (2001): Prevalence of physical activity during leisure time in the European Union. Medicine and Science in Sports and Exercise, 33 (7): 1142-1146.

Patrick, K., Grace, T. W., Lovato, C. Y. (1992): Health issues for college students. Annual Review of Public Health, 13: 253-268.

Pikó, B., Barabás, K., Markos, J. (1996): Health risk behaviour of a medical student population: report on a pilot study. Journal of the Royal Society of Health, 116(2):97-100.

Pikó, B. F., Fitzpatrick, K. M. (2004): Substance use, religiosity, and other protective factors among Hungarian adolescents. Addictive Behaviours, 29 (6):1095-1107.

Rappoport, L., Peters, G. R., Downey, R., McCann, T., Huff-Corzine, L. (1993): Gender and age differences in food cognition. Appetite, 20 (1): 33-52.

Reed, J. A., Philips, D. A. (2005): Relationships between physical activity and the proximity of exercise facilities and home exercise equipment used by undergraduate university students. Journal of American College Health, 53 (6): 285-290.

Serdula, M. K., Collins, M. E., Williamson, D. F., Anda, R. F., Pamuk, E., Byers, T. E. (1993): Weight control practices of U.S. adolescents and adults. Annals of Internal Medicine, 119 (7 Pt 2): 667-671.

Sima A., Pikó B., Simon T. (2004): Orvosegyetemi hallgatók pszichés egészségének és egészségkárosító magatartásának epidemiológiai vizsgálata. Orvosi Hetilap, 145 (3): $123-$ 129.

Stachenko, S. J., Reeder, B. A., Lindsay, E., Donovan, C., Lessard, R., Balram, C. (1992): Smoking prevalence and associated risk factors in Canadian adults. Canadian Heart Health Surveys Research Group. Canadian Medical Association Journal, 146 (11): 19891996.

Steptoe, A., Sanderman, R., Wardle, J. (1995): Stability and changes in health behaviours in young adults over 1 year period. Psychology and Health, 10: 155-169.

Steptoe, A., Wardle, J., Cui, W., Bellisle, F., Zotti, A. M., Baranyai, R., Sanderman, R. (2002a): Trends in smoking, diet, physical exercise and attitudes toward health in european university students from 13 countries, 1990-2000. Preventive Medicine, 35 (2):97-104.

Steptoe, A., Wardle, J., Cui, W., Baban, A., Glass, K., Pelzer, K., Tsuda, A., Vinck, J. (2002b): An international comparison of tobacco smoking, beliefs and risk awareness in university students from 23 countries. Addiction, 97 (12): 1561-1571.

Yusuf, S., Hawkin, S., Öunpuu, S., Dans, T., Avezum, A., Lanas, F., McQuenn, M., Budaj, A., Pais P., Varigos, J., Lishen, L. (2004): Effect of potentially modifiable risk factors associated with myocardial infarction in 52 countries (the INTERHEART study): casecontrol study. Lancet, 364 (9438): 937-952.

Yusuf, S., Reddy, S., Ounpuu, S., Anand, S. (2001): Global burden of cardiovascular diseases part I: general considerations, the epidemiologic transition, risk factors and impact of urbanization. Circulation, 104 (23): 2746-2753.

Wardle, J., Haase, A. M., Steptoe, A., Nillapun, M., Jonwutiwes, K., Bellisle, F. (2004): Gender differences in food choice: the contribution of health beliefs and dieting. Annals of Behavioral Medicine, 27 (2): 107-116.

Wardle, J., Solomons, W. (1994): Naughty but nice: A laboratory study of health information and food preferences. Health Psychology, 13:180-183.

Wardle, J., Steptoe, A. (1991): The European Health and Behaviour Survey: rationale, methods and initial results from the United Kingdom. Social Science and Medicine, 33 (8): 925-936.

World Health Organization (2003): The World Health Report: 2002. WHO Geneva. 
Köszönetnyilvánítás: Köszönetet szeretnénk mondani a MEKDSZ-nek, a segítőtársainknak, akik a kérdóíveket szétosztották, valamint a diákoknak, akik részt vettek a felmérésben.

A kutatás az alábbi pályázatok támogatásával készült: NKFP-01/002/2004 és OTKA Tudományos Iskola, TS 049785.

\author{
BARANYAI, RÉKA - BAKOS, GELLÉRT - STEPTOE, ANDREW - \\ WARDLE, JANE - KOPP, MÁRIA
}

\title{
HEALTH BEHAVIOUR, RISK KNOWLEDGE AND BELIEFS AMONG UNIVERSITY AND COLLEGE STUDENTS LINKED WITH HEARTH DISEASES
}

Coronary heart disease (CHD) is the leading cause of death worldwide. We explored the relationship between risk awareness, health beliefs and health or risk behaviour.

Methods: In the frame of the International Health and Behaviour Survey a cross-sectional, representative national survey was performed in university and college students. We applied self-reporting questionnaires. We included questions about risk behaviours relevant to the aetiology of CHD (smoking, lack of exercise, overweight, unhealthy dietary practices). Knowledge of risk factors and health beliefs were also assessed. 590 students participated in the study: $237(40.2 \%)$ men and 353 (59.8\%) women. The mean age of the sample was 21.8 years $( \pm 1.8)$. Multiple logistic regression models were used controlling for the effects of age and gender.

Results: Health behaviour: The prevalence of smoking was $19.4 \%$, of overweight $9.5 \% .84 \%$ of students recorded doing exercise at least once in the past 2 weeks. The prevalence of healthy dietary practices was lower compared to the measures mentioned above: $35.7 \%$ reported of having at least one serving of fruit per day, $30.7 \%$ of conscious effort of trying to reduce eating food with high fat and cholesterol content, whereas $23.9 \%$ ate fibre-rich food. Risk awareness: There was a high awareness of the influence of overweight $(93.2 \%)$ and dietary fat intake $(76.6 \%)$ on heart disease. In contrast, the knowledge of the connection between smoking or physical activity and heart disease was only $55.3 \%$ and $42.8 \%$, respectively. Health beliefs: Taking regular exercise proved to be the most important health activity $(93.1 \%)$, followed by eating fruit $(90.8 \%)$, keeping body weight in normal range $(87.8 \%)$ and not smoking $(86.4 \%)$. In contrast, fibre consumption and limiting dietary fat intake were accorded lower levels of importance for health (61.2\% and 59.3\%, respectively). Risk awareness showed almost no correlation with behaviour (only in smoking a positive association). Health beliefs, however, were strongly related to almost all examined behaviour.

Conclusions: The prevalence of risk behaviour of CHD is still high in students. Risk awareness did not prove to be associated with healthy behaviour. Nevertheless, students attaching a high importance to health behaviour were more often successful in implementing a healthy lifestyle.

Keywords: students, health behaviour, coronary heart disease, risk awareness, health beliefs 